\title{
Faktor-Faktor Yang Mempengaruhi Tingkat Pengetahuan Penggunaan Obat Bebas dan Obat Bebas Terbatas Untuk Swamedikasi Pada Masyarakat Dusun Krajan Kedungjambe Singgahan Tuban
}

\section{(Factors Affecting The Level Of Knowledge In The Use Of OTC And Limited OTC Medicines For Self-Medication In The Community Of Dusun Krajan Kedungjambe Singgahan Tuban}

\author{
Umul Farida*, Yogi Bhakti Marhenta, Wika Admaja, Amaliyah Salsabila \\ Institut Ilmu Kesehatan Bhakti Wiyata Kediri \\ JL. KH. Wachid Hasyim No. 65 Kediri, 64114, Indonesia \\ Email: alfridaumul200189@gmail.com
}

Info artikel:

Diterima:

08/09/21

Direview:

21/09/21

Diterbitkan:

$22 / 10 / 21$

\begin{abstract}
Abstrak
Swamedikasi adalah obat, baik berupa obat modern maupun obat tradisional, yang dipilih dan digunakan seseorang untuk melindungi diri dari penyakit dan gejala penyakit lainnya. Penelitian ini bertujuan untuk mengetahui pengaruh faktor pengetahuan, usia, pendidikan, pekerjaan, pengalaman, dan informasi terhadap tingkat pengetahuan tentang penggunaan obat bebas dan obat bebas terbatas untuk swamedikasi pada masyarakat Dusun Krajan Kedungjambe Singgahan Tuban. Penelitian ini menggunakan metode kuantitatif pendekatan cross sectional dengan jumlah sampel sebanyak 93. Teknik pengambilan sampel menggunakan purposive sampling sedangkan pengambilan data dilakukan dengan kuesioner online. Data dianalisis dengan menggunakan regresi linier berganda. Hasil penelitian menunjukkan bahwa usia pengaruh secara signifikan $(\mathrm{P}<0,05)$ terhadap pengetahuan penggunaan obat bebas dan obat bebas terbatas untuk swamedikasi. Sebaliknya, pendidikan, pekerjaan, pengalaman dan informasi tidak berpengaruh secara signifikan $(P>0,05)$ terhadap tingkat pengetahuan penggunaan obat bebas dan obat bebas terbatas untuk swamedikasi pada masyarakat Dusun Krajan Kedungjambe Singgahan Tuban.
\end{abstract}

Kata-kata Kunci: Pengetahuan, swamedikasi, obat bebas, obat bebas terbatas

\begin{abstract}
Self-medication is a drug, either modern or traditional medicine, that is chosen and used by a person to protect himself from diseases and other symptoms of disease. This study aimed to determine the influence of knowledge factor, age, education, occupation, experience, and information on the level of knowledge in the use of over-the-counter and limited over-the-counter medicines for self-medication in the community of Dusun Krajan Kedungjambe Singgahan Tuban. This study, involving a total of 93 samples, employed quantitative method with cross-sectional approach. The sample collection technique was purposive sampling utilizing an online questionnaire. Data were analysed using multiple linear regression. The results showed that age significantly affected $(\mathrm{P}<0.05)$ the knowledge in the use of over-the-counter and limited over-the-counter medicines for self-medication. On the contrary, there was no significant influence between education, occupation, experience, and information on the level of knowledge in the use of over-the-counter and limited over-the-counter medicines for self-medication in the community of Dusun Krajan Kedungjambe Singgahan Tuban (P $>0.05)$.
\end{abstract}

Key_Words: Knowledge, self-medication, over-the-counter medicine, limited over-the-counter medicine 


\section{PENDAHULUAN}

Kesehatan merupakan hal yang sangat penting dalam hidup. Seseorang yang merasa tidak enak badan akan bekerja keras untuk memulihkan kesehatannya kembali. Semua pihak akan mengupayakan kesembuhan dari suatu penyakit, antara lain dengan berobat ke dokter atau berobat sendiri (Level et al., 2019).

Obat adalah bahan atau paduan bahan, termasuk produk biologi yang digunakan untuk mempengaruhi atau mempelajari sistem atau keadaan fisiologis untuk menentukan diagnosis, pencegahan, penyembuhan, pemulihan, peningkatan kesehatan, dan konstrasepsi untuk manusia (Kemenkes RI, 2014).

Menurut peraturan Badan Kesehatan Dunia (WHO), swamedikasi adalah obat yang dipilih dan digunakan sesorang untuk melindungi diri dari penyakit dan gejala penyakit lainnya, termasuk obat modern dan obat tradisional ( Syafitri, Ratna, and Pristianty, 2017). Swamedikasi memberikan kontribusi yang besar dalam menjaga kesehatan, namun bila tidak dilakukan dengan benar, hal ini dapat menimbulkan penyakit yang tidak perlu, yaitu efek samping yang ditimbulkan oleh obat yang digunakan, penyakit tidak dapat disembuhkan atau bahkan timbul penyakit baru. Untuk menghasilkan pengobatan mandiri yang aman, efektif, dan terjangkau, masyarakat harus memiliki pengalaman dan keterampilan. Masyarakat sangat membutuhkan informasi yang jelas dan terpercaya agar kebutuhan obat dapat ditentukan berdasarkan alasan yang rasional ( Syafitri, Ratna, and Pristianty, 2017).
Menurut data Badan Pusat Statistik (BPS, 2014) tentang pengobatan sendiri, data medis yang direkam pada rentang waktu tahun 2002 sampai 2014 mencatat bahwa sebanyak 86,68\% penduduk menggunakan pengobatan modern, sebesar $32,90 \%$ penduduk menggunakan obat tradisional, sedangkan sebanyak $8,13 \%$ penduduk menggunakan obat lain-lain. Hasil ini juga diperkuat oleh indeks kesehatan BPS yang menunjukkan bahwa hanya sebesar 38,21\% penduduk berobat jalan (berobat ke dokter) (Badan Pusat Statistik, 2016). Berdasarkan data tersebut, terbukti bahwa sebagian besar masyarakat cenderung memilih untuk melakukan pengobatan sendiri dibandingkan berobat ke dokter (Syafitri, Ratna, and Pristianty, 2017).

Keuntungan praktik swamedikasi antara lain bersifat aman apabila obat digunakan sesuai aturan, dapat menghilangkan keluhan secara efektif, menghemat biaya, menghemat waktu, dan berperan dalam pengambilan keputusan terapi. Sebaliknya, kerugian dari praktik swamedikasi antara lain bersifat tidak aman dan bahkan merugikan pemakai apabila aturan pengobatan yang seharusnya tidak dipatuhi. Agar praktik swamedikasi dapat dilaksanakan secara aman, rasional, efektif, dan terjangkau, masyarakat perlu menambah pengetahuan dan keterampilannya dalam melakukan praktik swamedikasi. Masyarakat membutuhkan informasi yang jelas dan terpercaya, sehingga kebutuhan akan jenis atau jumlah obat dapat ditentukan berdasarkan alasan yang rasional (Sholiha, Fadholah and Artanti, 2019).

Dampak buruk dari praktik swamedikasi antara lain, dapat terjadi kesalahan pemilihan obat, 
timbul efek samping yang merugikan, dan dapat pula terjadi penutupan gejala-gejala yang dibutuhkan untuk ke penegakkan diagnosis oleh kedokter. Swamedikasi hendaknya dilaksanakan berdasarkan tingkat pengetahuan yang cukup untuk menghindari terjadinya penyalahgunaan obat, serta kegagalan terapi sebagai akibat penggunaan obat yang tidak sesuai. Menurut WHO di tahun 2012 pengetahuan yang cukup akan mempengaruhi seseorang dalam berperilaku atau melakukan sesuatu (Hidayati et al., 2017).

Berdasarkan konsep perilaku menurut Lawrence Green (Green, 1998), pengetahuan merupakan salah satu faktor predisposisi yang mempengaruhi kesehatan sesorang. Pengetahuan/kognitif merupakan bidang yang sangat penting dalam pembentukan perilaku seseorang. Masyarakat harus memahami beberapa pengetahuan dasar terkait pengobatan sendiri, termasuk mengidentifikasi gejala penyakit, memilih produk sesuai dengan indikasi penyakit, menggunakan obat sesuai dengan petunjuk yang tercantum pada label manual obat, dan memantau hasil pengobatan termasuk kemungkinan timbulnya efek samping obat (Syafitri, Ratna, and Pristianty, 2017).

Pada dasarnya tingkat pengetahuan seseorang dapat dipengaruhi oleh beberapa faktor. Menurut Notoatmodjo (2010), terdapat beberapa faktor yang dapat mempengaruhi pengetahuan seseorang, antara lain usia, pendidikan, pekerjaan, pengalaman, serta informasi

Berdasarkan hasil observasi awal yang dilakukan di Desa Kedungjambe yang merupakan salah satu desa yang berada di Kecamatan Singgahan Kabupaten Tuban, desa tersebut memiliki jumlah penduduk sebesar 3820 jiwa. Pada desa ini, hanya terdapat 3 orang bidan dan 2 orang perawat. Selain itu jarak antara desa dengan Puskesmas adalah $5 \mathrm{~km}$. Hal ini tentunya berdampak pada kemampuan penduduk Desa Kedungjambe untuk menjangkau fasilitas layanan kesehatan.

Sebagian perilaku swamedikasi di Indonesia berjalan secara tidak rasional dan hingga saat ini belum ada data mengenai penggunaan obat bebas dan obat bebas terbatas di Kecamatan Singgahan Kabupaten Tuban. Penelitian bertujuan untuk mengetahui:

1. tingkat pengetahuan penggunaan obat bebas dan obat bebas terbatas untuk swamedikasi pada masyarakat Dusun Krajan Kedungjambe Singgahan Tuban;

2. apakah usia berpengaruh terhadap tingkat pengetahuan penggunaan obat bebas dan obat bebas terbatas untuk swamedikasi pada masyarakat Dusun Krajan Kedungjambe Singgahan Tuban;

3. apakah pendidikan berpengaruh terhadap tingkat pengetahuan penggunaan obat bebas dan obat bebas terbatas untuk swamedikasi pada masyarakat Dusun Krajan Kedungjambe Singgahan Tuban;

4. apakah pekerjaan berpengaruh terhadap tingkat pengetahuan penggunaan obat bebas dan obat bebas terbatas untuk swamedikasi pada masyarakat Dusun Krajan Kedungjambe Singgahan Tuban;

5. apakah pengalaman berpengaruh terhadap tingkat pengetahuan penggunaan obat bebas dan obat bebas terbatas untuk swamedikasi pada masyarakat Dusun Krajan Kedungjambe Singgahan Tuban; 
6. apakah informasi berpengaruh terhadap tingkat pengetahuan penggunaan obat bebas dan obat ebas terbatas untuk swamedikasi pada masyarakat Dusun Krajan Kedungjambe Singgahan Tuban.

\section{II.METODE PENELITIAN}

Studi ini menggunakan metode penelitian kuantitatif dengan teknik pengumpulan data melalui kuesioner tentang pendapat sampel yang diambil dari populasi tertentu pada masa penelitian yang tertentu (Sugiyono, 2012). Analisis yang digunakan adalah deskriptif analitik yaitu survei dengan pendekatan seksional silang (cross sectional), yang bertujuan untuk mengetahui hubungan antara dua variabel atau lebih dengan proses pengambilan data yang hanya dilakukan sekali saja untuk masing-masing variabel penelitian (Notoatmodjo, 2012). Populasi dalam penelitian ini adalah masyarakat Dusun Krajan, Desa Kedungjambe Singgahan Tuban yang memenuhi kriteria inklusi dan eksklusi. Adapun kriteria inklusi antara lain: usia 17 hingga 55 tahun, pernah menggunakan obat oral secara swamedikasi untuk mengatasi penyakit ringan dalam 1-3 bulan terakhir, dan bersedia bekerja sama dalam pengisian kuesioner penelitian. Ukuran sampel dalam penelitian ini dihitung dengan menggunakan rumus Slovin (Siregar, 2015), dan didapatkan kebutuhan sampel penelitian sebanyak 93 orang. Teknik sampling yang digunakan adalah purposive sampling, yaitu didasarkan pada suatu pertimbangan tertentu yang dirancang oleh peneliti sendiri, atas dasar ciri atau sifat populasi yang sudah diketahui sebelumnya (Notoatmodjo, 2018). Penelitian ini diawali dengan menetapkan jumlah responden yang akan diteliti, kemudian peneliti membuat grup media sosial berupa aplikasi WhatsApp. Selanjutnya peneliti membagikan tautan kuesioner dengan menggunakan Google Formulir dan dilakukan pengolahan data sesuai hasil yang terkumpul dari responden. Penelitian ini menggunakan analisis univariat regresi linier berganda.

\section{HASIL DAN PEMBAHASAN}

Tabel 1. Gambaran Pengetahuan Penggunaan Obat Bebas dan Obat Bebas Terbatas untuk Swamedikasi.

\begin{tabular}{|c|c|c|c|c|}
\hline \multirow{3}{*}{$\begin{array}{c}\text { Pertanyaan } \\
\text { No. }\end{array}$} & \multicolumn{4}{|c|}{ Jawaban } \\
\hline & \multicolumn{2}{|c|}{ Benar } & \multicolumn{2}{|c|}{ Salah } \\
\hline & $\mathrm{N}$ & $\%$ & $\mathrm{~N}$ & $\%$ \\
\hline 1 & 79 & 84,9 & 14 & 15,1 \\
\hline 2 & 79 & 84,9 & 14 & 15,1 \\
\hline 3 & 77 & 82,8 & 16 & 17,2 \\
\hline 4 & 80 & 86,0 & 13 & 14,0 \\
\hline 5 & 91 & 97,8 & 2 & 2,2 \\
\hline 6 & 46 & 49,5 & 47 & 50,5 \\
\hline 7 & 50 & 53,8 & 43 & 46,2 \\
\hline 8 & 64 & 68,8 & 29 & 31,2 \\
\hline 9 & 81 & 87,1 & 12 & 12,9 \\
\hline 10 & 87 & 93,5 & 6 & 6,5 \\
\hline 11 & 89 & 95,7 & 4 & 4,3 \\
\hline 12 & 52 & 55,9 & 41 & 44,1 \\
\hline
\end{tabular}

Tabel 2. Tingkat Pengetahuan Responden terhadap Penggunaan Obat Bebas dan Obat Bebas Terbatas untuk Swamedikasi.

\begin{tabular}{llcc}
\hline No. & Kategori & Frekuensi & Persentase (\%) \\
\hline 1. & Baik & 47 & 50,6 \\
\hline 2. & Cukup & 43 & 46,2 \\
\hline 3. & Kurang & 3 & 3,2 \\
\hline & Total & 93 & 100 \\
\hline
\end{tabular}

Tabel 3. Hasil Uji Normalitas Data $\begin{array}{ccc}\text { Variabel } & \begin{array}{c}\text { Statistik Uji } \\ \text { Kolmogrov Smirnov }\end{array} & \text { Nilai Sig. }\end{array}$

\begin{tabular}{lll}
\hline Pengetahuan dan & 0,070 & 0,200
\end{tabular}

Faktor Pengetahuan

Tabel 4. Hasil Uji Analisis Regresi Linier Berganda

\begin{tabular}{lcc}
\hline \multicolumn{1}{c}{ Variabel } & t hitung & Sig \\
\hline Usia $(\mathrm{X} 1)$ & 2,096 & 0,039 \\
\hline Pendidikan $(\mathrm{X} 2)$ & 0,863 & 0,390 \\
\hline Pekerjaan $(\mathrm{X} 3)$ & 0,559 & 0,578 \\
\hline Pengalaman $(\mathrm{X} 4)$ & 0,029 & 0,977 \\
\hline Informasi $(\mathrm{X} 5)$ & $-1,070$ & 0,287 \\
\hline Keterangan: & & \\
$\mathrm{t}$ tabel & $=\mathrm{t}(\mathrm{a} / 2 ; \mathrm{n}-\mathrm{k}-1)$ & \\
& $=\mathrm{t}(0,05 / 2 ; 93-5-1)$ \\
& $=\mathrm{t}(0,025 ; 87)$ & \\
& $=1,988$
\end{tabular}


-Umul Farida dkk-. Faktor-Faktor Yang Mempengaruhi Tingkat Pengetahuan Penggunaan Obat Bebas dan Obat Bebas Terbatas Untuk Swamedikasi Pada Masyarakat Dusun Krajan Kedungjambe Singgahan Tuban- hlm.1-9

Pengetahuan Penggunaan Obat Bebas dan Bebas Terbatas untuk Swamedikasi

Tabel 1 menunjukkan bahwa persentase tertinggi jawaban 'benar' dijumpai pada pertanyaan nomor 5 "apakah paracetamol adalah obat yang digunakan untuk mengobati demam dan sakit kepala?" dengan jumlah jawaban 'benar' sebanyak 91 responden (97,8\%). Dengan demikian hampir seluruh responden memahami bahwa obat paracetamol yang memiliki kandungan analgesik dan antipiretik, sering digunakan untuk mengobati demam dan sakit kepala karena obat ini dinilai relatif aman untuk penggunaan pada anak dan orang dewasa (Indira, Artini and Ernawati, 2018). Demam merupakan suatu kondisi pada saat suhu tubuh berada diatas normal yaitu $38^{\circ} \mathrm{C}$. Terdapat berbagai macam cara untuk penanganan demam yang dapat digunakan untuk menurunkan panas, yaitu penanganan tanpa obat dan penanganan dengan obat. Penanganan dengan obat dapat dilakukan dengan memberikan obat antipiretik pada saat suhu tubuh anak $>39^{\circ} \mathrm{C}$. Obat antipiretik yang umum digunakan saat ini adalah obat parasetamol atau ibuprofen karena kedua obat tersebut dinilai relatif aman untuk digunakan pada anak dan usia dewasa (Indira, Artini and Ernawati, 2018).

Pada tabel 2, terlihat bahwa persentase jawaban terendah yang menjawab 'benar' adalah pertanyaan nomor 6 "jika paracetamol diminum sebagai obat demam tanpa resep dokter, apakah obat boleh diminum hingga lebih dari 2 hari?" dengan jumlah jawaban 'benar' sebanyak 46 responden (49,5\%). Hal ini menunjukkan bahwa separo responden belum memahami bahwa penggunaan paracetamol dalam dosis tinggi dan jangka waktu yang lama dapat meningkatkan resiko hepatotoksik (Zulizar, 2013). Selain itu penggunaan kortikosteroid oral dalam jangka waktu yang lama dapat menimbulkan efek samping yang cukup serius seperti moonface, hiperglekimia, hipertensi (Nuryati, 2017). Tabel 2 menunjukkan bahwa 47 responden $(50,6 \%)$ memiliki pengetahuan baik, 43 responden $(46,2 \%)$ memiliki pengetahuan cukup, sedangkan 3 responden $\quad(3,2 \%)$ memiliki pengetahuan kurang. Seorang responden dapat dikategorikan masing-masing ke dalam kelompok tingkat pengetahuan 'baik', tingkat pengetahuan 'cukup', dan tingkat pengetahuan 'kurang', apabila mereka memperoleh jawaban 'benar' berturut-turut dalam $76-100 \%, 56-75 \%$, dan < 56\%. Hasil tersebut menunjukkan bahwa upaya pengobatan sendiri yang dilakukan oleh masyarakat tidak terlepas dari kebenaran informasi tentang obat yang diterima. Jika obat bebas dan obat bebas terbatas digunakan dengan benar, maka obat tersebut dapat sangat membantu masyarakat dalam pengobatan sendiri secara aman dan efektif. Namun pada kenyataannya seringkali pengobatan sendiri dilakukan secara tidak rasional karena penggunaan obat yang salah, sehingga dapat merugikan masyarakat karena pemakaian obat tidak disertai dengan informasi yang jelas mengenai obat tersebut, seperti indikasi, kesesuaian dosis, potensi efek samping dan interaksi antara obat dengan makanan. Ketidakrasionalan pemakaian obat ini terjadi karena keterbatasan pengetahuan masyarakat tentang informasi obat dan kemampuan berkomunikasi mengenai informasi obat tersebut. Terkadang masyarakat tidak dapat mengungkapkan informasi mengenai pengobatan yang ingin mereka tanyakan kepada apoteker, sehingga informasi yang diterima oleh masyarakat masih terbatas (Pratiwi et al., 2016). 
Sebelum dilakukan uji regresi linier berganda dilakukan uji normalitas. Apabila nilai signifikansi $<0,05$ berarti data tidak terdistribusi secara normal dan jika nilai signifikansi > 0,05 maka data terdistribusi secara normal (Santosa, 2014). Data yang diperoleh pada penelitian ini terdistribusi secara normal, karena hasil uji normalitas menunjukkan nilai signifikansi 0,200 (>0,05).

\section{Regresi linier berganda pada pengaruh pengetahuan}

Pengaruh faktor pengetahuan terhadap tingkat pengetahuan masyarakat dilakukan dengan uji metode analisis regresi linier berganda. Analisis regresi linier berganda merupakan analisis yang mengkaji hubungan antara satu variabel terikat (dependent variable) dengan dua atau lebih variabel bebas (independent variable). Hasil uji analisis (Tabel 3) menunjukkan bahwa terdapat hubungan antara faktor pengetahuan dengan tingkat pengetahuan masyarakat (nilai signifikansi $<0,05$ atau $\mathrm{t}$ hitung $>\mathrm{t}$ tabel).

Hasil analisis statistik regresi linier seperti terlihat pada Tabel 4, menunjukkan bahwa nilai signifikansi faktor usia sebesar 0,039 $(<0,05)$, yang berarti bahwa usia berpengaruh secara signifikan terhadap tingkat pengetahuan masyarakat. Hasil penelitian ini sejalan dengan penelitian yang dilakukan oleh Suwaryo and Yuwono (2017).

Usia dapat mempengaruhi daya tangkap dan pola pikir seseorang. Semakin bertambah usia seseorang, semakin berkembang pula daya tangkap dan pola pikirnya sehingga pengetahuan yang diperolehnya semakin baik. Pada rentang usia 2035 tahun, seseorang akan berperan lebih aktif dalam kehidupan sosial di tengah masyarakat, serta lebih banyak melakukan persiapan demi suksesnya karier dan penyesuaian diri di usia tuanya. Selain itu mereka lebih banyak memanfaatkan waktu untuk membaca. Dilaporkan bahwa kemampuan intelektual, memecahkan masalah, dan kemampuan verbal tidak mengalami penurunan pada usia ini (Suwaryo and Yuwono, 2017).

Berbeda dengan faktor usia, ternyata faktor pendidikan tidak berpengaruh secara nyata terhadap pengetahuan masyarakat, dengan nilai signifikansi 0,390 (>0,05), seperti terlihat pada Tabel 4. Hasil penelitian ini sejalan dengan hasil yang dilaporkan oleh Ar-Rasily and Dewi (2016), yaitu pendidikan tidak berpengaruh terhadap pengetahuan masyarakat.

Menurut Carter (2011), semakin tinggi tingkat pendidikan seseorang maka semakin mudah pula orang tersebut unuk memperoleh informasi, sehingga semakin banyak pula pengalaman yang dimilikinya, dalam hal ini terutama pengetahuan masyarakat tentang penggunaan obat bebas dan obat bebas terbatas. Seseorang dengan pengalaman yang luas akan berdampak pada persepsi diri yang terbangun. Oleh sebab itu pendidikan merupakan faktor yang sangat penting dalam kehidupan seharihari. Tingkat pendidikan akan mempengaruhi persepsi seseorang. Seseorang yang berpendidikan tinggi juga memiliki kemampuan penalaran yang tinggi (Suwaryo and Yuwono, 2017). Pengetahuan itu sendiri dipengaruhi faktor pendidikan formal. Ilmu sangat erat kaitannya dengan pendidikan, dan masyarakat diharapkan memiliki wawasan yang lebih luas setelah mengenyam pendidikan tinggi. Namun hal ini tidak berarti bahwa seseorang dengan latar belakang pendidikan rendah pasti juga memiliki pengetahuan yang rendah pula. Hal ini disebabkan oleh fakta bahwa peningkatan pengetahuan tidak diperoleh hanya melalui 
pendidikan formal, namun dapat diperoleh melalui pendidikan non formal (Kusuma and Putri, 2012).

Sama halnya dengan tingkat pendidikan, ternyata faktor pekerjaan juga terbukti tidak berpengaruh secara nyata terhadap pengetahuan masyarakat, dengan nilai signifikansi 0,578 (> 0,05). Hasil ini tidak sejalan dengan penelitian yang dilaporkan oleh Suwaryo and Yuwono (2017), yang menyatakan bahwa pekerjaan berpengaruh terhadap pengetahuan.

Pekerjaan merupakan suatu kegiatan atau aktivitas seseorang untuk memperoleh penghasilan guna memenuhi kebutuhan hidupnya sehari-hari. Pekerjaan adalah mereka yang bekerja di institusi, kantor, perusahaan dengan upah dan gaji baik berupa uang ataupun barang. Lingkungan pekerjaan dapat membuat seseorang memperoleh pengalaman dan pengetahuan, baik secara langsung maupun tidak langsung. Bagi sebagian besar orang, pekerjaan dipandang bukan sebagai sumber kesenangan, namun cara mencari nafkah yang membosankan, dilakukan secara berulang, dan penuh tantangan. Semakin lama seseorang bekerja, semakin banyak pula pengetahuan yang diperolehnya (Susila, 2015).

Sejalan dengan faktor tingkat pendidikan dan pekerjaan, hasil analisis statistik regresi linier terhadap pengalaman menunjukkan bahwa pengalaman juga tidak berpengaruh secara nyata terhadap pengetahuan masyarakat, dengan nilai signifikansi 0,977 (>0,05). Temuan pada penelitian ini tidak sejalan dengan penelitian terdahulu (ArRasily and Dewi, 2016), yang menyatakan bahwa pengalaman berpengaruh terhadap pengetahuan masyarakat.

Pengalaman merupakan sumber pengetahuan. Oleh sebab itu pengalaman pribadi dapat berperan sebagai upaya untuk memperoleh pengetahuan. Hal ini dilakukan dengan cara mengulang kembali pengalaman seseorang yang telah didapatkan pada masa lalu (Ar-Rasily and Dewi, 2016). Setiap orang mempunyai pengalaman yang berbeda walaupun melihat suatu obyek yang sama, hal ini dipengaruhi oleh: tingkat pengetahuan dan pendidikan seseorang, pelaku atau faktor pada pihak yang mempunyai pengalaman, faktor obyek atau target yang dipersepsikan dan faktor situasi dimana pengalaman itu dilakukan (Notoatmodjo, 2012).

Tabel 4 menunjukkan pula bahwa faktor informasi tidak berpengaruh secara nyata terhadap pengetahuan masyarakat, dengan nilai signifikansi 0,287 (>0,05). Hasil ini sejalan dengan penelitian yang dilakukan oleh Ar-Rasily and Dewi (2016).

Menurut Erfandi (2009), kemudahan untuk memperoleh informasi dapat membantu seseorang untuk secara cepat memperoleh pengetahuan yang baru. Sumber informasi adalah data yang diolah ke dalam suatu bentuk yang memiliki arti sehingga memberikan nilai nyata dan terasa bagi seseorang yang menerimanya dalam membuat keputusan saat itu ataupun keputusan di masa mendatang (Susila, 2015). Informasi dapat diperoleh melalui pendidikan formal maupun non formal, dan dapat pula diperoleh dari media cetak maupun media elektronik, seperti televisi, komputer, buku, radio, surat kabar dan majalah. Seseorang yang mudah memperoleh informasi akan lebih cepat mendapatkan pengetahuan (Ar-Rasily and Dewi, 2016).

\section{KESIMPULAN}

Berdasarkan pada hasil penelitian ini dapat disimpulkan hal-hal sebagai berikut: 
1. Tingkat pengetahuan sebagian besar masyarakat Dusun Krajan Kedungjambe Singgahan Tuban tentang penggunaan obat bebas dan obat bebas terbatas untuk swamedikasi dinilai baik.

2. Terdapat pengaruh yang signifikan antara usia dengan pengetahuan masyarakat Dusun Krajan Kedungjambe Singgahan Tuban tentang penggunaan obat bebas dan obat bebas terbatas untuk swamedikasi.

3. Tidak ada pengaruh yang signifikan antara pendidikan dengan pengetahuan masyarakat Dusun Krajan Kedungjambe Singgahan Tuban tentang penggunaan obat bebas dan obat bebas terbatas untuk swamedikasi.

4. Tidak ada pengaruh yang signifikan antara pekerjaan dengan pengetahuan masyarakat Dusun Krajan Kedungjambe Singgahan Tuban tentang penggunaan obat bebas dan obat bebas terbatas untuk swamedikasi.

5. Tidak ada pengaruh yang signifikan antara pengalaman dengan pengetahuan masyarakat Dusun Krajan Kedungjambe Singgahan Tuban tentang penggunaan obat bebas dan obat bebas terbatas untuk swamedikasi.

6. Tidak ada pengaruh yang signifikan antara informasi dengan pengetahuan masyarakat Dusun Krajan Kedungjambe Singgahan Tuban tentang penggunaan obat bebas dan obat bebas terbatas untuk swamedikasi.

\section{DAFTAR PUSTAKA}

Ar-Rasily, O. and Dewi, P. 2016. Faktor-faktor yang Mempengaruhi Tingkat Pengetahuan Orang Tua mengenai Kelainan Genetik Penyebab Disabilitas Intelektual di Kota Semarang. Jurnal Kedokteran Diponegoro. 5(4), pp. 1422-1433.
Badan Pusat Statistik. 2014. Persentase Penduduk yang Mengobati Sendiri pada Tahun 20022014. Jakarta: Badan Pusat Statistik.

Badan Pusat Statistik. 2016. Persentase Penduduk yang Mengobati Sendiri Selama Sebulan Terakhir. Jakarta: Badan Pusat Statistik.

Carter, W. 2011. Disaster Manegement: A Disaster Manager's Handbook. Manila: ADB.

Erfandi. 2009. Pengetahuan dan Faktor-faktor yang Mempengaruhi. Diunduh 17 Juli 2012. http://forbetterhealth.wordpress.com/2009/04 /19/pengetahuan-dan-faktor-faktor-yangmempengaruhi.

Green, L. W. 1998. Health Promotion Planning: An Education and Environmental Approach. California : Mayfield Publising Company.

Hidayati, A. et al. 2017. Obat Bebas Terbatas untuk Swamedikasi pada Masyarakat RW 8 Morobangun Jogotirto Berbah. Jurnal Ilmiah Manuntung. 3(2), pp. 139-149.

Indira S. M. A. N., Artini, I. G. A. and Ernawati, D. K. 2018. Pola Penggunaan Parasetamol atau Ibuprofen sebagai Obat Antipiretik Single Therapy pada Pasien Anak. E-Jurnal Medika. 7(8), pp. 1-13.

Kementrian Kesehatan Republik Indonesia. 2014. Peraturan Menteri Kesehatan Republik Indonesia Nomor 35 Tahun 2014 tentang Standar Pelayanan Kefarmasian di Apotek. Jakarta: Kementrian Kesehatan RI. p.3.

Kusuma, P. and Putri, D. 2012. Pengaruh Tingkat Pendidikan, Pengetahuan, Sikap dan Terpaan Iklan Layanan Masyarakat KB Versi Shireen Sungkar dan Teuku Wisnu di TV terhadap Perilaku KB pada Wanita atau Pria dalam Usia Subur. Interaksi. 1(1), pp. 46-56.

Level, T. H. E. et al. 2019. Gambaran Pengetahuan Tenaga Teknik Kefarmasian tentang Pengobatan Influenza secara Swamedikasi Berdasarkan Tempat Bekerja. Jurnal Farmasetis. 8(1), pp. 1-8.

Notoatmodjo, S. 2010. Promosi Kesehatan \& Ilmu Perilaku. Jakarta: PT. Rineka Cipta. 
Notoatmodjo, S. 2012. Promosi Kesehatan dan Perilaku Kesehatan. Jakarta: PT. Rineka Cipta.

Notoatmodjo, S. 2018. Metodologi Penelitian Kesehatan. Jakarta: PT. Rineka Cipta.

Nuryati. 2017. Farmakologi. Jakarta: Pusdik SDM Kesehatan Kementrian Kesehatan RI.

Pratiwi, H. et al. 2016. Pengaruh Edukasi terhadap Pengetahuan, Sikap, dan Kemampuan Berkomunikasi atas Informasi Obat. Kartika Jurnal Ilmiah Farmasi. 4(1), pp. 10-15.

Santosa, S. 2014. Panduan Lengkap SPSS versi 20 Edisi Revisi. Jakarta: Elex Media Komputindo.

Sholiha, S., Fadholah, A. and Artanti, L. O. 2019. Tingkat Pengetahuan Pasien dan Rasionalitas Swamedikasi di Apotek Kecamatan Colomadu. Pharmaceutical Journal of Islamic Pharmacy. 3(2), pp. 1-11.

Siregar, S. 2015. Statistik Parametrik untuk Penelitian Kuantitatif. Jakarta: Bumi Aksara.

Sugiyono. 2012. Metode Penelitian Kuantitatif Kualitatif dan $R \& D$. Bandung: Alfabeta.

Susila, P. I. Y. 2015. Faktor-faktor yang Berhubungan dengan Pengetahuan Penggunaan Obat Generik pada Masyarakat di Wilayah Kerja Puskesmas Padang Panyang Kabupaten Naga Raya 2015. Skripsi, FKM UTU, Aceh.

Suwaryo, P. A. W. and Yuwono, P. 2017. Faktor faktor yang Mempengaruhi Tingkat Pengetahuan Masyarakat dalam Mitigasi Bencana Alam Tanah Longsor. Urecol 6th, pp. 305-314.

Syafitri, I. N., Ratna, I. H. and Pristianty, L. 2017.

Hubungan Tingkat Pengetahuan terhadap Penggunaan Obat Parasetamol Rasional dalam Swamedikasi. Jurnal Farmasi dan Ilmu Kefarmasian Indonesia. 4(1), pp. 19-26.

Zulizar, A. A. 2013. Pengaruh Parasetamol Dosis Analgesik Terhadap Kadar Serum Glutamat Oksaloasetat Transaminase Tikus Wistar Jantan. Skripsi, FK UNDIP, Semarang. 